\title{
Knowledge and practices of self-medication among adolescents
}

\author{
Dimple C. Gabriel ${ }^{1}$, Bhavani Bangarkodi Balakrishna ${ }^{2 *}$
}

\begin{abstract}
${ }^{1}$ Department of Child Health Nursing, The Oxford College of Nursing, Bangalore, Karnataka, India
${ }^{2}$ Department of Child Health Nursing, Sri Shankara College of Nursing, Basavanagudi, Bangalore, Karnataka, India
\end{abstract}

Received: 08 July 2021

Accepted: 07 August 2021

\section{*Correspondence:}

Dr. Bhavani Bangarkodi Balakrishna,

E-mail: bhavanibb@yahoo.com

Copyright: ( ) the author(s), publisher and licensee Medip Academy. This is an open-access article distributed under the terms of the Creative Commons Attribution Non-Commercial License, which permits unrestricted non-commercial use, distribution, and reproduction in any medium, provided the original work is properly cited.

\begin{abstract}
Background: Self-medication begins in early adolescence, often during the middle school years. By the age of 16, nearly all adolescents have taken medicine independently for minor illnesses and become more involved with managing chronic conditions. Taking medications without a doctor's prescription, even if the ailment is minor, can have serious repercussions. A large number of potent drugs such as pain relievers, cough remedies, anti-allergies, laxatives, antibiotics, antacids and vitamins are sold over-the-counter (OTC). The present study aimed to assess "the knowledge and practices of self-medication among adolescents in selected colleges, Bengaluru, India with a view to develop an informational booklet.

Methods: The study was done using a survey design. Simple random sampling technique was adopted to select 100 adolescents from a pre-university college. A socio demographic Performa, a self-reported structured questionnaire to assess knowledge and practice checklist regarding self-medication was used to collect the data. Descriptive and inferential statistics was used for analysis.

Results: Self-medication use was reported by $94 \%$ of the adolescents. Analgesics $65 \%$, antipyretics $51 \%$, cough and cold medications $49 \%$, vitamins $35 \%$, antibiotics $26 \%$, and antacids $19 \%$, were cited as the most common types of medication taken. Around $45 \%$ adolescents had poor knowledge about self-medication. There was a low negative correlation between knowledge and practice of self-medication among participants. (Pearson's r=-0.44).

Conclusions: The practice of self-medication among adolescent was very high. A significant number of adolescents had inadequate knowledge regarding self-medication and its consequences. Therefore, potential problems of selfmedication should be emphasised to the adolescents. Need based information booklet was prepared and disseminated to the adolescents.
\end{abstract}

Keywords: Adolescents, Self-medication, Knowledge, Practice, Prevalence

\section{INTRODUCTION}

Medications are one of the main options in the cure, treatment, and prevention of numerous medical conditions. In fact, medications are the primary treatment client associate with restoration of health. ${ }^{1}$ Selfmedication is the act or process of medicating oneself especially without the advice of a physician. The term was used in $1839 .^{2}$

Self-medication is a global phenomenon and potential contributor to human pathogen resistance to antibiotics.
The adverse consequences of such practices should always be emphasized to the community and steps to curb it. Rampant irrational use of antimicrobials without medical guidance may result in greater probability of inappropriate, incorrect, or undue therapy, missed diagnosis, delays in appropriate treatment, pathogen resistance and increased morbidity. ${ }^{3}$

According to WHO self-medication is defined as the selection and use of medicines by individual to treat selfrecognized illness or symptoms. Self-medication is one element of self-care. ${ }^{4}$ The increase in self-care is due to a 
number of factors. These factors include socio-economic factors, lifestyles, ready access to drugs, increased potential to manage certain illness through self-care, public health and environmental factors, greater availability of medicinal products, and demographical and epidemiological factors. ${ }^{4}$

Self-medication can take place through the consumption of industrialized or manipulated medicines or the use of home remedies and include various type of activities such as acquiring medicines without a prescription, resubmitting old prescriptions to purchase medicines, sharing medicines with relatives or member of one social circle, using left over medicines stored at home or failing to comply with professional prescription either by prolonging it or interrupting it too early or decreasing or increasing the originally prescribed dosage. ${ }^{5}$

The consumption of medications can be considered as an indirect indicator of the quality of health care services. Children and adolescents are strongly susceptible to the irrational use of drugs with and without medical control. Economic, political and cultural factors have contributed to the growth and spread of self-medication worldwide. These factors are related with aspects such as the great availability of products in the current days; the state of health that a pharmaceutical agent may represent; irresponsible publicity; pressure to convert prescriptiononly drugs into OTC drugs; quality of health care; difficult access to health care services in poor countries. ${ }^{6}$

Self-medication begins in early adolescence, often during the middle school years. By the age of 16 , nearly all adolescents have taken medicine independently. There is considerable variation, however, in the age at which independent self-care is achieved, as well as in the accuracy of medication and dosage selection. ${ }^{8}$

There are many public and professional concerns about irrational use of drugs. The prevalence rate is high all over the world up to $76 \%$ in Karachi ${ }^{9}$, Jordan $78.5 \%,{ }^{10}$ Nigeria 54.6\% New Delhi India, 92.8\%. ${ }^{9-12}$

Self-medication is dangerous and it has wide range of ill effects. The ill effects include bleeding in the stomach, acidity, nausea, vomiting, diarrhoea, constipation, dizziness, rashes, and headaches, dryness in the mouth, stomach pain, and blurred vision, ringing in the ear, restlessness, confusion, reduced concentration, and allergic reaction like swelling of lips, face, and tongue. It may also increase blood pressure which counteract the effect of some blood pressure medicines, cardiac failure. ${ }^{6}$

In developing country like India, the system of selfmedication is flourishing due to various factors like socioeconomic factors, lifestyle, previous experience of treating a similar illness, ready access to drugs and the increased potential to manage mild illness through selfcare. Self-medication is a problem that has the potential to harm society at a large as well as individual patient.
Self-medication provides a lower cost alternative for people who cannot afford the cost of clinical services which all contribute to the spread of self-medication. ${ }^{7}$ Studies on self-medication knowledge and practice among pre university college adolescents are limited in India. This study aimed to assess the knowledge and practices of self-medication among adolescents with a view to develop an informational booklet.

\section{METHODS}

A survey design was adopted in the present study. The study was conducted at a pre university college in Bengaluru city, Karnataka, India. The study was done from September 2013 to January 2014. The target population was adolescent students in the age group of 16 to 18 years. The accessible population comprised of pre university college students from a selected pre-university (PU) college in the age group of 16-18 years. Sample size of the study was 100 adolescents, studying in $1^{\text {st }}$ year and $2^{\text {nd }}$ year PU class, selected by simple random sampling technique using lottery method. Out of total 224 adolescents, studying in $1^{\text {st }}$ and $2^{\text {nd }}$ year PU class, there were a total of 114 and 110 students in science and commerce group respectively. Each student was assigned a unique number. The numbers were placed in a bowl and mixed thoroughly and 100 number tags, 50 each from, science and commerce group were picked up. All the individuals bearing the numbers picked by the researcher were taken as the samples for the study. The inclusion criteria were, students willing to participate in the study and those available during the period of data collection. The data collection tools included, a socio-demographic data sheet, a structured knowledge questionnaire to elicit the knowledge on self-medication and a structured practice checklist to elicit the self-reported practice regarding self-medication. The knowledge questionnaire had 15 items related to self-medication. Each item had four options with one correct answer. The maximum score for correct response was "one" and incorrect response "Zero". Thus for 15 items the maximum obtained score was 15 . To interpret the level of knowledge, the scores were arbitrarily categorised as poor: less than 5 score $(33.33 \%)$, average: between 6-10 score $(33.33 \%-66.66 \%)$ and good: above 10 score $(66.6 \%)$. The practice checklist consisted of 16 items related to self-reported practice of self-medication, which had yes or no option. A score of '1' was awarded for 'yes' and 'zero' for 'no'. Pre testing of the tool was carried out among 20 PU College students selected by simple random sampling technique in a similar PU college.

\section{Ethical consideration}

Prior to study institutional ethics committee approval was obtained. Official permission from the authority of selected pre-university college. The purpose of the study and the written consent was obtained from the subjects. 


\section{Statistical analysis}

The data obtained was analysed on the basis of the objectives of the study using descriptive and inferential statistics. Descriptive statistics such as frequency, percentage, mean, and standard deviation were used for analysis of demographic characteristics. knowledge and practice scores. Chi square test to find the association of knowledge and practice scores with selected demographic variables and Pearson's correlation was done for correlation between the knowledge and practice scores.

\section{RESULTS}

\section{Description of sample characteristics}

Out of 100 adolescents $42 \%$ were 17 years old, $39 \%$ were in the age group of $\leq 16$ years, $57 \%$ were females and $43 \%$ were males, $52 \%$ of the adolescents were studying in $12^{\text {th }}$ grade and remaining $48 \%$ were in 11 th grade, majority (84\%) belonged to the Hindu religion, $50 \%$ each were from rural and urban area, $39 \%$ of the adolescent's mothers had high school education, $45 \%$ of the adolescents' father's qualification was high school education. Most $(65 \%)$ of the adolescents' mothers were homemakers, $47 \%$ of the adolescents' fathers were labourers, $64 \%$ of adolescents reported seeking information regarding medication from family and friends (Table 1).

\section{Over all knowledge score regarding self-medication}

A little more than fifty percentage adolescents had average knowledge, $45 \%$ had poor knowledge and only $3 \%$ had good knowledge about self-medication (Table 2).

\section{Practice of self-medication}

In present study, an overwhelming majority (94\%) of the adolescents were practicing self-medication, $(88 \%)$ were not consulting doctors in case of mild ailments, and 67\% were reading information before taking self-medication. According to illness, majority (66\%) of adolescents took medication for pain, $61 \%$ for fever, $48 \%$, for respiratory illness and $19 \%$ for digestive system illness.

The reason for self-medication were reported by $31 \%$ adolescents as, reading article from paper and magazine, $41 \%$ stated that cost of medicine is less than consulting a doctor, little more than half $(53 \%)$ reasoned it as minor symptoms, $32 \%$ adolescents took self-medication during emergency, $31 \%$ quoted the reason as saving time.
The different methods used to buy medications were: mentioning the name of the drug (36\%), by describing the symptom of illness (65\%), showing a sample of the drug $(27 \%)$, and showing the old prescription $(26 \%)$.

Majority $(78 \%)$ of the adolescents checked the indication, $75 \%$ checked the dosage and $88 \%$ of adolescents checked the expiry date before taking self-medication. Only $17 \%$ of the adolescents had visited pharmacy more than 4 times over the last 6 months at the time of study.

With regard to the form of drug consumed, majority (90\%) of the adolescents had taken tablet form of medication, $22 \%$ liquid and only $1 \%$ had taken injection.

Out of the total adolescents, $22 \%$ of the adolescents had experienced side effects after self-medication, $31 \%$ had taken double dose, if they forgot to take one dose, $51 \%$ of respondents stopped medication when symptoms were relieved and half of them $(50 \%)$ avoided self-medication during fasting (Table 3 ).

\section{Types of drugs used for self-medication}

Majority (65\%) of the adolescents had taken analgesics, $49 \%$ cough and cold medications, $26 \%$ antibiotics, $35 \%$ vitamins, $51 \%$ antipyretics and $19 \%$ antacids.

\section{Association of knowledge and practice score with demographic variables of adolescents}

Chi square analysis was done to find the association between the knowledge scores and socio-demographic variables of adolescents. There was a significant association between knowledge and the age of the participants. Whereas gender, education, religion, area of living, mother's education, father's education, mother's occupation, father's occupation and source of information were not found to have any significant association with knowledge score. There was no significant association between practices scores and demographic variables.

\section{Correlation between knowledge and practice score}

The knowledge and practice mean score obtained by the adolescents was 6.09 and 14.79 with standard deviation of 1.070 and 5.04. There was a low negative correlation between knowledge and practice of adolescents on selfmedication which was not significant (Table 5).

Table 1: Socio-demographic characteristics of the adolescents, $(n=100)$.

\begin{tabular}{|lll|}
\hline Characteristics & Frequency $(\mathbf{f})$ & Percentage $(\boldsymbol{\%})$ \\
\hline Age (years) & & \\
\hline$\leq 16$ & 39 & 39 \\
\hline 17 & 42 & 42 \\
\hline 18 & 19 & 19 \\
\hline
\end{tabular}




\begin{tabular}{|c|c|c|}
\hline Characteristics & Frequency (f) & Percentage (\%) \\
\hline \multicolumn{3}{|l|}{ Gender } \\
\hline Male & 43 & 43 \\
\hline Female & 57 & 57 \\
\hline \multicolumn{3}{|l|}{ Level of education } \\
\hline $11^{\text {th }}$ grade & 48 & 48 \\
\hline $12^{\text {th }}$ grade & 52 & 52 \\
\hline \multicolumn{3}{|l|}{ Religion } \\
\hline Christian & 08 & 08 \\
\hline Hindu & 84 & 84 \\
\hline Muslim & 08 & 08 \\
\hline \multicolumn{3}{|l|}{ Area of living } \\
\hline Rural & 50 & 50 \\
\hline Urban & 50 & 50 \\
\hline \multicolumn{3}{|l|}{ Education of mother } \\
\hline No formal education & 02 & 02 \\
\hline Primary school & 34 & 34 \\
\hline High school & 39 & 39 \\
\hline PUC & 21 & 21 \\
\hline Degree and above & 04 & 04 \\
\hline \multicolumn{3}{|l|}{ Education of father } \\
\hline No formal education & 01 & 01 \\
\hline Primary school & 20 & 20 \\
\hline High school & 45 & 45 \\
\hline PUC & 26 & 26 \\
\hline Degree and above & 08 & 08 \\
\hline \multicolumn{3}{|c|}{ Occupation of mother } \\
\hline Private employee & 11 & 11 \\
\hline Labourer & 24 & 24 \\
\hline Home maker & 65 & 65 \\
\hline \multicolumn{3}{|l|}{ Occupation of father } \\
\hline Govt. employee & 06 & 06 \\
\hline Business & 45 & 45 \\
\hline Labourer & 47 & 47 \\
\hline Unemployed & 02 & 02 \\
\hline \multicolumn{3}{|c|}{ Source of information } \\
\hline Mass media & 12 & 12 \\
\hline Health personnel & 23 & 23 \\
\hline Family and friends & 64 & 64 \\
\hline Print media & 01 & 01 \\
\hline
\end{tabular}

Table 2: Knowledge of adolescents on self-medication, $(\mathbf{n}=100)$.

\begin{tabular}{|lll|}
\hline Level of knowledge & Frequency (f) & Percentage (\%) \\
\hline Poor (0-5) & 45 & 45 \\
\hline Average (6-10) & 52 & 52 \\
\hline Good (11-15) & 3 & 3 \\
\hline
\end{tabular}

Table 3: Practice of self-medication $(n=100)$.

\begin{tabular}{|lcl|}
\hline $\begin{array}{l}\text { Practice questions } \\
\text { Taking self-medication }\end{array}$ & Frequency $(\mathbf{f})$ & Percentage $(\boldsymbol{\%})$ \\
\hline Yes & 94 & 94 \\
\hline No & 6 & 6 \\
\hline Consulting doctor in case of minor ailments & \\
\hline Yes & 12 & 12 \\
\hline No & 88 & 88 \\
\hline
\end{tabular}


Practice questions

Frequency (f)

Seeking information before taking a medication not prescribed by a doctor

Yes 67

No

33

67

33

The minor illness for taking self-medication

Respiratory illness (like cough, cold)

$\begin{array}{lll}\text { Yes } & 48 & 4 \\ \text { No } & 52 & 52\end{array}$

Digestive system problems (diarrhoea, acidity etc.)

\begin{tabular}{|c|c|c|}
\hline Yes & 19 & 19 \\
\hline No & 81 & 81 \\
\hline \multicolumn{3}{|c|}{ Fever } \\
\hline Yes & 61 & 61 \\
\hline No & 39 & 39 \\
\hline \multicolumn{3}{|c|}{ Pain (headache, back pain etc) } \\
\hline Yes & 66 & 66 \\
\hline No & 34 & 34 \\
\hline
\end{tabular}

The reasons that influence you for self-medication

Article from paper, magazine

$\begin{array}{lll}\text { Yes } & 31 & 31 \\ \text { No } & 69 & 69\end{array}$

The cost of medicine is less than consulting a doctor

$\begin{array}{lll}\text { Yes } & 41 & 41\end{array}$

No $\quad 59 \quad 59$

If the symptoms are minor

$\begin{array}{lll}\text { Yes } & 53 & 53\end{array}$

No 47

47

In case of emergency

$\begin{array}{lll}\text { Yes } & 32 & 32\end{array}$

$\begin{array}{lll}\text { No } & 68 & 68\end{array}$

It takes a longer time to wait and see a doctor

$\begin{array}{lll}\text { Yes } & 31 & 31\end{array}$

No 69

69

The different ways to get medications are

Mentioning the name of the drug

$\begin{array}{lll}\text { Yes } & 36 & 36 \\ \text { No } & 64 & 64\end{array}$

Telling the symptom of your illness

$\begin{array}{lll}\text { Yes } & 65 & 65\end{array}$

$\begin{array}{lll}\text { No } & 35 & 35\end{array}$

$\begin{array}{lll}\text { Showing a sample of the drug } & & \\ \text { Yes } & 27 & 27\end{array}$

$\begin{array}{lll}\text { No } & 73 & 73\end{array}$

Showing the old prescription forms

$\begin{array}{lll}\text { Yes } & 26 & 26\end{array}$

$\begin{array}{lll}\text { No } & 74 & 74\end{array}$

Checking the indication before taking medication

$\begin{array}{lrr}\text { Yes } & 78 & 78 \\ \text { No } & 22 & 22\end{array}$

Checking the dosage before taking medication

$\begin{array}{lll}\text { Yes } & 75 & 75\end{array}$

No $25 \quad 25$

Checking the expiry date before taking medicine

$\begin{array}{lrr}\text { Yes } & 88 & 88 \\ \text { No } & 12 & 12\end{array}$

No. of adolescents, who have visited pharmacy more than 4 times to purchase drugs without prescription, over the 


\begin{tabular}{|c|c|c|}
\hline Practice questions & Frequency (f) & Percentage $(\%)$ \\
\hline \multicolumn{3}{|l|}{ last 6 months } \\
\hline Yes & 17 & 17 \\
\hline No & 83 & 83 \\
\hline \multicolumn{3}{|c|}{ Form of the medication mostly consumed } \\
\hline \multicolumn{3}{|c|}{ Tablet } \\
\hline Yes & 90 & 90 \\
\hline No & 10 & 10 \\
\hline \multicolumn{3}{|l|}{ Liquid } \\
\hline Yes & 22 & 22 \\
\hline No & 78 & 78 \\
\hline \multicolumn{3}{|l|}{ Injection } \\
\hline Yes & 1 & 1 \\
\hline No & 99 & 99 \\
\hline \multicolumn{3}{|c|}{ No. of adolescents who had side effects as of self-medication } \\
\hline Yes & 22 & 22 \\
\hline No & 78 & 78 \\
\hline \multicolumn{3}{|c|}{ No. of adolescents who took double dose, when they forgot to take the drug } \\
\hline Yes & 31 & 31 \\
\hline No & 69 & 69 \\
\hline \multicolumn{3}{|c|}{ No. of adolescents who stopped medication before the complete dose, when symptoms were relieved } \\
\hline Yes & 51 & 51 \\
\hline No & 49 & 49 \\
\hline \multicolumn{3}{|c|}{ Avoiding the medicine during fasting } \\
\hline Yes & 50 & 50 \\
\hline No & 50 & 50 \\
\hline
\end{tabular}

Table 4: Types of drugs used for self-medication, $(n=100)$.

\begin{tabular}{|c|c|c|}
\hline Practice & Frequency (f) & Percentage $(\%)$ \\
\hline \multicolumn{3}{|c|}{ Type of drugs taken by self } \\
\hline \multicolumn{3}{|c|}{ Analgesics } \\
\hline Yes & 65 & 65 \\
\hline No & 35 & 35 \\
\hline \multicolumn{3}{|c|}{ Cough and cold medications } \\
\hline Yes & 49 & 49 \\
\hline No & 51 & 51 \\
\hline \multicolumn{3}{|c|}{ Antibiotics } \\
\hline Yes & 26 & 26 \\
\hline No & 74 & 74 \\
\hline \multicolumn{3}{|l|}{ Vitamins } \\
\hline Yes & 35 & 35 \\
\hline No & 65 & 65 \\
\hline \multicolumn{3}{|c|}{ Antipyretics } \\
\hline Yes & 51 & 51 \\
\hline No & 49 & 49 \\
\hline \multicolumn{3}{|l|}{ Antacids } \\
\hline Yes & 19 & 19 \\
\hline No & 81 & 81 \\
\hline
\end{tabular}

Table 5: Correlation between knowledge and practice score, $(n=100)$.

\begin{tabular}{|lllll|} 
Area & Mean & SD & $\begin{array}{l}\text { Pearson's } \\
\text { R }\end{array}$ & P value \\
\hline Knowledge & 6.09 & 1.070 & -0.44 & 0.661 \\
\hline Practice & 14.79 & 5.04 & -0.4 & \\
\hline
\end{tabular}




\section{DISCUSSION}

Several studies have been done on self-medication prevalence and practices among different populations. Most common study population in the literature has been among young adults, and college students. It's a human tendency to seek solution for health issues on their own at first. Self-medication begins during early adolescence. Several factors interplay for practicing self-medication. The consequences of self-medication can be deleterious. It is important to create awareness regarding problems and adverse effect of the drugs consumed without consultation. Studies on self-medication practices among pre university adolescents are limited. Our study focused on self-medication prevalence, knowledge and practices among late adolescents between 16 to 18 years of age.

The present study revealed a very high prevalence of selfmedication. Majority (94\%) of the adolescents were practicing self-medication. Our findings showed a higher prevalence of self-medication compared to the findings of the studies on different group of young population; (81.5\% adolescents), (78.6\%. pre university adolescents), (92\% among high school students), (92\% among medical students), (87\% technical university students), (88\% engineering students), (77.3\% pharmacy students), (42\% engineering students), (56.6\% children and adolescents), (69\% secondary school students), $(57.05 \%$ medical students).,13-22

The high prevalence in our study of younger group is very concerning and can be related to availability and easy accessibility of over the counter and prescription medicines. Multiple number of medical stores and pharmacy can be located in every street in major cities in India. Another contributing factor can be that, the pharmacist does no insist on producing medical prescription.

In the present study, little more than half of the adolescents $(52 \%)$ had average knowledge and $45 \%$ had poor knowledge on self-medication. Similar studies on self-medication also have reported poor knowledge or lack of knowledge in certain aspects of selfmedication. ${ }^{20,23-25}$ Low knowledge level of adolescents can be a factor for inappropriate medication practices. Knowledge regarding medication can help in an individual's ability to use medication judiciously. Hence knowledge enhancement interventions such as school and college-based seminars, information pamphlets, selfinstructional modules can be used to promote medication literacy.

With regard to the types of illness, in the present study most $(66 \%)$ of the adolescents were taking medicines for relief of pain, $61 \%$ for fever, followed by respiratory ailments (49\%) and GI problems (19\%). These findings are comparable to the self-medication studies in other countries. ${ }^{14,15,22,23,26}$ From the findings of our study and the literature on studies of self-medication it is evident that the most common ailments for which self-medication was practiced include fever, aches and pains, respiratory symptoms of common cold, sore throat, diarrhoea, and nutritional supplementation.

In the current study, the reasons or factors that influenced self-medication were mainly quoted by $53 \%$ adolescents as having only minor symptoms and adolescents believed that there was no necessity to consult doctor. Similar factors were reported in studies along with the other quoted reasons for self-medication such as, "quick relief", "lack of time" and high consultation fees, time saving, prescriber's ineffective medications, mild illness. ${ }^{13,18,22,26,27}$ Belief in the efficacy of the drugs, past experience, availability, low cost and saving of time. Parents were the main factor that influenced students' self- medication. ${ }^{26}$ Mathias et al mentioned the reason for self-medication was severe illness, not able to visit any doctor; busy schedule and previous prescription. ${ }^{13}$

It is a human tendency to seek quick relief and solutions to most problems. Hence for various health related problems too individuals try to seek medical relief by looking for convenient resources. In current study, $1 / 4^{\text {th }}$ of the adolescents also mentioned that the cost of medicine is less than cost of consultation fees for some ailments. The practice of availing medication by showing old prescription is common and reported in other studies too. ${ }^{13}$

The adolescents used different methods to buy the drugs. The most common method was by describing the symptom of illness $(65 \%)$, mentioning the name of the drug $(36 \%)$, by showing a sample of the drug $(27 \%)$, and showing the old prescription $(26 \%)$. Similar methods of acquiring medicines were reported in other studies. ${ }^{13,28}$ The role of pharmacist, nurses and other health professional is pivotal in prevention of self-medication and making informed choices.

In the present study, the common type of drugs taken by adolescents were analgesics $(65 \%)$ and half the adolescents had taken antipyretics, $49 \%$ consumed cough and cold medication, nutritional supplements $(35 \%)$, and antibiotics $(26 \%)$. These findings are congruent to that of other studies. ${ }^{13,14}$ In comparison Badiger et al reported higher percentage use of antipyretics, analgesics, antihistamines and antibiotics. Onohwosafe, additionally found the use of anti-malaria and drugs blood tonics. ${ }^{26}$ Compared to our findings James et al and Albatti et al showed more than eighty percent subjects using analgesics..$^{23,29}$

In our study nearly one fourth of adolescents had taken antibiotics. Consumptions of antibiotics is hazardous as individuals may develop resistance to antibiotics. The adolescents may not complete the course of antibiotics due to lack of knowledge, which can have a grave health consequence. 
In the present study percentage of adolescents who experienced side effect after self-medication was more $(22 \%)$ which is higher compared to other studies; Badiger et al 5\% and Mathias et al 5.2\%.13,15

In this study more than three-fourth of the adolescents checked the indications, dosage and expiry date of the medicines before consuming it. Tablet was the most common form of medicine and one case of taking injectable form of medication. Self-medication with injectable form of drug is a very dangerous practice as it can lead to serious consequences, without guidance of health professional. However, our study did not investigate the route and administration of injection. Further, $31 \%$ of adolescents took double dose, when they forgotten to take the drug and half of the adolescents stopped medication before the complete dose, when their symptoms were relieved. These high-risk practices can be related to lack of knowledge and ignorance. It has been observed that even with prescribed medications sometimes patients stop taking complete course of medication including antibiotics. In view of these facts strategies to promote rational use of drug is very important.

The present study results showed that there was a low negative correlation between knowledge and practice of adolescents on self-medication which was not significant statistically. This is in contrast to a similar study wherein, a significant correlation between self-medication practice and knowledge, among the respondents was found. ${ }^{30} \mathrm{In}$ the current study the main source of information was family and friends followed by health personnel which is consistent to another study. ${ }^{31}$

Present study has limitation such as small sample size, recall bias, subjectivity, poor memory and omission of some of the self-medication drugs, as self-reported questionnaire was used for data collection.

\section{CONCLUSION}

Self-medication is a concerning issue. The study demonstrated inadequate knowledge and very high prevalence of self-medication among the adolescents. The findings of the study provide a baseline data for the health professionals to create awareness among the adolescents regarding OTC drugs, which will in turn help to reduce health problems and complications caused by the use of OTC drugs in adolescents. All health care workers including nurses play a vital role in health promotion, including aiding clients to develop responsible, informed self-medication and self-care competency. Nurses have a key role in consumer education process in all healthcare setting about responsible self-medication including: when to seek advice from health professionals; how to monitor effects, including adverse events; deciding when to stop medicines; use of patient information leaflets; and storage and disposal of unused and expired products. School health nurses can play a vital role in conducting educational programs for adolescents on prevention of self-medication. Based on the findings of the study, an information booklet was prepared on self-medication and given to all adolescents.

Funding: No funding sources

Conflict of interest: None declared

Ethical approval: The study was approved by the Institutional Ethics Committee

\section{REFERENCES}

1. Shoemaker SJ, Ramalho D. Understanding the meaning of medications for patients: the medication experience. Pharm world Sci. 2008;30(1)86-91.

2. Merriam-Webster.com. Dictionary SV. "selfmedication,"., Available at: https://www.merriamwebster.com/dictionary/self-medication. Accessed on June 29, 2021.

3. Bennadi D. Self-medication: A current challenge. J Basic Clin Pharmacy. 2014;5(1).

4. World Health Organization. The Role of the pharmacist in self-care and self-medication: report of the 4th WHO Consultative Group on the Role of the Pharmacist, The Hague, The Netherlands, 1998. Available https://apps.who.int/iris/handle/10665/65860. Accessed on June 29, 2021.

5. Filho L, Antonia I. A qualitative approach to selfmedication. Cad Saude Publica. 2004;20(6):1661-9.

6. Francis S V T, Pereira, Selm. Medication in children and adolescents. J pediatria. 2007;8(3):133-6.

7. Phalke VD, Phalke DB, Durgawate PM. Selfmedication practice in rural Maharashtra. IJCM. 2006;31(1):34-5

8. Marcia L. Buck. Self-medication by adolescents. Pediatric Pharmacotherapy. 2007;13(5):1-4.

9. Zafar SN, Syed R, Waqar S, Zubairi AJ, Vaqar T. Self-medication amongst university students of Karachi: prevalence, knowledge and attitudes. Aga Khan University, JPMA. 2008;58(4).

10. Alkhatatbeh MJ, Alefan Q, Alqudah MA. High prevalence of self-medication practices among medical and pharmacy students: a study from Jordan. Int J Clin Pharmacol Ther. 2016;54(5):390-8.

11. Akande-Sholabi W, Ajamu AT, Adisa R. Prevalence, knowledge and perception of self-medication practice among undergraduate healthcare students. J Pharm Policy Pract. 2021;14(1):49.

12. Kumar V, Mangal A, Yadav G, Raut D, Singh S. Prevalence and pattern of self-medication practices in an urban area of Delhi, India. Med J DY Patil Vidyapeeth. 2015;8(1):16-20.

13. Mathias EG, D'souza A, Prabhu S. Self-Medication Practices among the Adolescent Population of South Karnataka, India. J Environmental Public Health. 2020.

14. Almalak H, Albluwi I, Alkhelb DA. Students' attitude toward use of over-the-counter medicines 
during exams in Saudi Arabia. Saudi Pharmaceutical J. 2013;1(2):107-12.

15. Badiger S, Kundapur R, Jain A, Kumar A, Pattanshetty S, Thakolkaran N et al. Self-Medication patterns among medical students in South India. Australas Med J. 2012;5(4):217-20.

16. Rohit K, Mohan L, Pandey M. Evaluation of selfmedication among professional students in North India: proper statutory drug control must be implemented. Asian J Pharmaceutical Clin Res. 2010;3(1):60-4.

17. Mansi M, Singh U. Self-Medication practices among college students: A cross sectional study in Gujarat. Natl J Med Res. 2013;3(3):257-60.

18. Reetesh M, Papiya B, Jain S. Study of selfmedication among the people of Bhopal region. IRJP. 2011;2(12):163-5.

19. Hussain A, Khanum A. Self-medication among university students of Islamabad, Pakistan-a preliminary study. Southern Med Review j. 2008;1(1):14-6.

20. Pereira FS, Bucaretchi F, Stephan C, Cordeiro R. Self-medication in children and adolescents. J Pediatr. 2007;83(5):453-8.

21. Mwambete KD. Irrational antibiotic usage in boarding secondary school settings in Dares Salaam. East Afr J Public Health. 2009;6(2):200-4.

22. Banerjee I, Bhadury T. Self-medication practice among undergraduate medical students in a tertiary care medical college, West Bengal. J Postgrad Med. 2012;58(2):127-31.

23. James H, Handu SS, Al Khaja KA, Otoom S, Sequeira RP. Evaluation of the knowledge, attitude and practice of self-medication among first-year medical students. Med Princ Pract. 2006;15(4):2705 .
24. Hsiao F Y, Lee J I, Huang W F. Survey of medication knowledge and behaviors among college students in Taiwan. Am J Pharmaceutical Education. 2006;70(2)30.

25. Ghosh S, Vimal V, Gupta A, Chaudhary R. Evaluation of the practice of self-medication among college students in West Uttar Pradesh. IJPPR. 2010;1(1):14-8.

26. Onohwosafe PS, Olaseha O. Factors influencing selfmedication among students of Abadina College, Ibadan, Nigeria. Inter $\mathbf{J}$ Health Pro and Edu. 2013:42(1):27-32.

27. Sharma A, Madaan A, Nagappa AN. medication storage and self-medication practice among the youth in Karnataka region, India. Int J Pharmaceutical Sci Res. 2012;3(8):2795-800.

28. Gupta P, Bobhate P, Shrivastava SR. Determinants of self-medication practices in an urban slum community. AJPCR. 2011;4(3)54-7.

29. Albatti TH, Alawwad S, Aldueb R, Alhoqail R, Almutairi R. The self-medication use among adolescents aged between 13-18 years old; Prevalence and behaviour Riyadh- Kingdom of Saudi Arabia, from 2014-2015. Int J Pediatrics Adolescent Med. 2017;4(1):19-25.

30. Marilia GC. Self-medication in university students from the city of Rio Grande, Brazil. BMC Public Health. 2012;12:33:

31. Auta A, Omale S. Medicine vendors: self-medication practices and medicine knowledge. N Am J Med Sci. 2012;4(1):24-8.

Cite this article as: Gabriel DC, Balakrishna BB. Knowledge and practices of self-medication among adolescents. Int J Contemp Pediatr 2021;8:1557-65. 